\title{
Protection of Women's Political Rights Based on Islamic Point of View
}

\author{
Palmawati Taher ${ }^{1}$, Rena Yulia ${ }^{2}$ \\ \{palmawatitaher@untirta.ac.id ${ }^{1}$, renayulia@ untirta.ac.id ${ }^{2}$ \} \\ University of Sultan Ageng Tirtayasa, Indonesia ${ }^{1,2}$
}

\begin{abstract}
This paper tries to provide an overview of the extent to which Islam views women's political rights, then also compares its application in several countries that apply the Islamic legal system and Indonesia as a country with a majority Muslim population. This research is a legal research with a normative doctrinal approach which is carried out through literature study by examining and examining primary, secondary and tertiary legal materials. However, in conducting research, researchers also conduct interviews if necessary with practitioners or experts in the field of law and politics.
\end{abstract}

Keywords: Politics, Human Rights, Women, and Islam.

\section{Introduction}

Various activities and mobilization over the years, women's participation in the political stage as a parallel relationship with men has not yet reaps to success. Today, the step of linking democracy with gender equality is a widely accepted principle. One important factor of any democratic framework is the principle of human rights, including the political rights of men and women.

Apart from that gender inequality can also be seen from the lack of representation of women in various areas of life, both in government systems, social organizations, religious institutions, customs, and political organizations and in the field of law. This state of affairs implies something that impressed as an unjust treatment of women. People tend to trust men more in the social activities of women. This situation build up a thought on the negative impact, as if women are seen as low and should not play an active role in various aspects of life, especially in politics.

Early feminism perspectives in political science tend to focus on issues such as gender differential in representation and political participation. Feminist criticism in mainstream political theory is slower to develop. ${ }^{1}$

Humans are the khalifah of God on earth. His duties prosper the earth for human welfare. ${ }^{2}$ These are sacred texts that imply the necessity of man to politics. Al Qurthubi ${ }^{3}$ states that the

${ }^{1}$ Veronica Mottier, Feminsime dan Teori Gender: Kembalinya Negara, dalam Geral F. Gaus dan Chandran Kukathas, Handbook Teori Politik, (Terj. Derta Sri Widowatie), Bandung, Nusa Media bekerjasama dengan LPIP, 2013, hlm. 631.

${ }^{2}$ Lihat dalam Surah Al-Baqarah 2:30 dan Surah Hud 11:61

${ }^{3}$ Quraish syihab, Membumikan Al-Qur'an: Fungsi dan Peran Wahyu dalam Kehidupan Masyarakat cet.1, Bandung, Mizan Media Utama, 2007. 
verse in this sura al-Baqarah shows the necessity of human appoint the government leaders to regulate the order of life of the people, enforce the law correctly and realize justice and other important things necessary for life together. These are all political matters.

The political discourse of Islam, politics (al siyasah) is simply formulated as a way of organizing the affairs of life together to achieve prosperity in the world and happiness in the hereafter (tadbir al syu-un al 'ammah li mashalihihim fi al ma'asy wa sa'adatihim fi al ma'ad). That way politics in this sense is really a vast space, as large as the living space itself. It appears in both domestic and public spaces, cultural and structural, personal and communal spaces. But politics mention in the minds of many people had been narrowed into terms for practical politics, structural politics, power struggles for self-interest or some people, no longer for the benefit of the common people and for the long future.

According to classical Islamic politics ${ }^{4}$, the leader (nashb al imam) is obliged in the category of fardh kifayah (collective duty) on the basis of religious argument and rational thought. Al Ghazali in Al I'tiqad fi al Iqtishad called this duty as something "dharuri" (inevitability) within the framework of the progress of the teachings of God. While alMawardi asserted that the existence of government is needed to protect the religion and regulation of the world (Al Ahkam al-Sulthaniyah).

As a collective necessity, then political participation in this matter is not a requirement of every citizen. But the more citizens who participated, legitimacy of power will get stronger and relatively more guarantee of stability.

Islamic law is the law of God. That is, the law in the form of the rule of God which aims to regulate human relationship with God (worship) as well as human relationships with society, the relationship between humans and daily human activities (muamalah). Islamic law is universal. The provision concerning all areas of the law.

Munakahat regulates marriage and divorce. Wirasah governs inheritance. Muamalat establishes a trade system. Jinayat is concerned with criminal law. Al ahkam as sulthaniyah concerns on the state administration and state administration. Siyar establishes peace and war in the field of law among nations. Finally, Mukhas greatly governs the power of the courts and the judiciary. ${ }^{6}$

\section{Related Problems}

a. What is the Relation between Islam, Women and Human Rights?

b. How does Islam view to protect women's political rights?

\footnotetext{
${ }^{4}$ Munawir Syadzali. Islam dan Tata Negara, Jakarta: UI Press. 1996. hlm. 1-2.

5 Muhammad Al-Ghazali, Al-Islam wa Al-Thaqat Al-Mu'attalat, Kairo, Dar Al-Kutub Al-Haditsah, 1964. sebagaimana yang dikutip dalam YusufQardhawi, Fiqh Daulah, Jakarta:Rabbani Press. 1997.

${ }^{6}$ Ronald H. Anderson, Pemilihan dan Pengembangan Media untuk Pembelajaran (terj. Yusufhadi Miarso, dkk), Jakarta, Raja Grafindo Persada, 1994.
} 


\section{Research Methods}

This research is a normative law research using normative case study in the form of legal behavior product, for example studying law. The subject of the study is the law that is conceptualized as the norm or rule that is in society and becomes the reference of everyone's behavior. Thus normative legal research focuses on the inventory of positive law, legal principles and doctrines, the discovery of law in the case of concrete, systematic law, and levels of synchronization, comparative law and legal history. ${ }^{7}$

Based on the above explanation, the author decided to use normative legal research methods to research and write the discussion of this research as a method of legal research. The use of normative research methods in research and writing efforts is based on the compatibility of the theory with research methods required by the author.

In legal research there are several approaches, with this approach the researcher will get information from various aspects of the issue that is being tried to find the answer. Approach method in this research is approach of regulation of legislation (statue approach). ${ }^{8} \mathrm{~A}$ normative study must necessarily use the approach of legislation, because that will be examined are the various legal rules that become the focus as well as the central theme of a study. While data analysis conducted in this research is done with more qualitative approach that reveal data (legal material) as much as possible so that problem discussed may be more transparent. The qualitative approach allows researchers to elaborate the data obtained comprehensively and the description results become more accountable.

\section{Theory}

\subsection{Human Rights}

Human Rights (fundamental) To understand the nature of human rights, it will first explain the basic definition of rights Definitively "right" is a normative element that serves as a guide to behave, protecting freedom, immunity and ensuring human opportunities in maintaining its dignity and prestige. ${ }^{9}$ The right itself has the following elements: ${ }^{10}$

a. Right owner;

b. Scope of application of rights;

c. Parties willing to exercise rights.

All three elements are integrated into the basic understanding of rights. Thus the right is a normative element inherent by each human being which in its application lies in the scope of the rights of equality and rights of freedom associated with the interaction between individuals or with agencies.

Right is something to be gained. In relation to the acquisition of rights there are two theories namely McCloskey's theory and Joel Feinberg's theory. According to McCloskey's theory it is stated that giving rights is to be done, owned or done. Whereas in Joel Feinberg's

\footnotetext{
${ }^{7}$ Abdulkadir Muhammad. Hukum dan Penelitian Hukum. Cet. 1. Bandung: PT. Citra Aditya Bakti 2004. hlm. 52

${ }^{8}$ Peter Mahmud Marzuki, Penelitian Hukum. Cet 2. Jakarta: Kencana. 2008. Hlm 29

${ }^{9}$ Tim ICCE UIN Jakarta. Demokrasi, Hak Asasi Manusia dan Masyarakat Madani, Jakarta : Prenada Media,2003, hlm. 199.

${ }^{10}$ Tim ICCE UIN Jakarta. ...Ibid.... hlm 199.
} 
theory it is stated that giving full rights is the unity of legitimate claims (benefits gained from the exercise of rights accompanied by the implementation of obligations). Thus the benefits can be gained from the exercise of rights when accompanied by the implementation of obligations. It means that between rights and obligations are two things that cannot be separated in the manifestation. Therefore when a person demands a right must also perform obligations. $^{11}$

John Locke stated that human rights are rights given directly by God the Creator as a natural right. Therefore, there is no power in the world that can uproot it. This right is very basic (fundamental) for human life and life and is a natural right that cannot be separated from and in human life. ${ }^{12}$

In Law Number 39 Year 1999 on Human Rights Article 1 states that:

"Human Right is a set of rights attached to the nature and existence of human beings as creatures of God Almighty and is a gift that must be respected, upheld and protected by the state, law, government and everyone for the honor and protection human dignity and prestige.

Based on some formulation of the definition of Human Rights, obtained a conclusion that human rights are the inherent rights of human nature and fundamental as a gift of God that must be respected, maintained and protected by every individual, society or country. Thus the nature of respect and protection of human rights is to maintain the safety of human existence as a whole through the action of balance that is the balance between the rights and obligations, as well as the balance between the interests of individuals and the public interest. ${ }^{13}$

\subsection{The concept of human rights in Islam}

To understand the concept and the nature of human rights in Islam, it will first explain the basic definition of human rights. In Arabic, human rights are known as (Haqq al-Insânî alAsâsî or also called Haqq al-Insânî ad-Darûrî), which consists of three words, namely:

a. The word right (haqq) means: property, belonging, authority, power to do something, and is something to be gained.

b. The word man (al-insân) means: the intelligent being, and serves as the subject of the law.

c. Asasi (asâsî) means: basic or principal.

In terminologically, human rights in the perception of Islam, Muhammad Khalfullah Ahmad has given the understanding that human rights are the inherent rights of human nature and fundamental as a mandate and grace of Allah SWT which must be maintained, respected and protected by every individual, society or country. Even Ibn Rushd further emphasizes that human rights in Islamic perceptions have provided a format of protection, security, and anticipation of the various human rights that are primary (darûriyyât) owned by every human being. Such protection comes in the form of anticipation of things that will threaten the existence of the soul, the existence of honor and descent, the existence of material possessions, the existence of the mind, and the existence of religion. ${ }^{14}$

${ }^{11}$ Tim ICCE UIN Jakarta. ...Ibid..., hlm. 200

${ }^{12}$ Masyhur Effendi. Dimensi dan Dinamika Hak Asasi Manusia dalam Hukum Nasional dan Internasional, Jakarta, Ghalia Indonesia, 1994, hlm. 3.

${ }^{13}$ Tim ICCE UIN Jakarta ...... Op., cit....., hlm. 201.

${ }^{14}$ Abul A'la Maududi, Human Right in Islam, Aligharh: 1978, hlm. 10. Lihat pula: Wahbah az-Zuhaili, al-Fiqh al-Islam Wa Adillauhu, Juz I, Siria: Dar al-Fikr, 1984, hlm. 18-19. 
Thus, the nature of respect and protection of human rights in the concept of Islam is to maintain the safety of human existence as a whole and the balance, namely the balance between rights and obligations, as well as the balance between private interests with the public interest. So in fulfilling and demanding rights cannot be separated from the fulfillment of obligations that must be implemented. So also in the interests of individuals can not damage the interests of the people (public interest). Therefore, the fulfillment, protection and respect for human rights must be accompanied by the fulfillment of KAM (human rights obligations), and TAM (Human Responsibility), in private life, community life, and state. ${ }^{15}$ So it can be concluded that the essence of human rights is the integration of HAM, KAM, and TAM that take place in a synergistic and balanced. All of this (HAM, KAM, and TAM) is a blessing and a grace as well as a trust that will be held accountable before the divine court of God Almighty.

Some kinds of human rights in Islam, among them:

a. Right to live.

The most important human rights promoted by Islam are the right to live and to respect human life. It has been stated explicitly by Allah SWT on QS. 5 (al-Ma'idah): $32 .{ }^{16}$ According to Shaykh Syaukat Husayn, Islam commands his people to respect this right to life, even to the infant still in his mother's womb. Moreover, Islam not only takes into account the glory and dignity of the human person while he is alive, his dignity remains glorified, until his death, with taken care of his body, bathed, memorized, prayed and buried well and full of sincerity. ${ }^{17}$

b. Right to acquire life or economic rights.

Speaking of economic rights, Islam has taught every individual to be able to meet his personal needs and his family in accordance with the achievements of life skills owned. However, behind the property it contains, in it contained the rights of others, especially among the dhai'fa of the poor, who are expelled through zakat, infak, alms funds (ZIS). It is in accordance with the word of Allah SWT QS. 51 (adz-Dzariyat): $19 .{ }^{18}$

c. Right to freedom and freedom.

Islam strictly prohibits the practice of slavery, in the form of an independent person being a servant of light, then traded. As has been explained by the Prophet Muhammad in his hadith narrated by Imam Bukhari and Ibn Majah which comes from 'Amr ibn' Ash, namely: There are three categories of people that I myself will sue on the Day of Judgment. Among them are those who cause an independent to be a servant sahaya, then sell it and eat the money from the sale.

\footnotetext{
${ }^{15}$ Muhammad Muhammad adh-Dahahham, Huquq al-Insan fi al-Islam wa Ri ayatihi li al-Qayyim wa alMa`ani al-Insaniyyah, Cairo: Syirkah al-Misriyyah, 1971, hlm. 45-46.

${ }^{16}$ Terjemahan dari ayat tersebut: "Oleh karena itu Kami tetapkan (suatu hukum) bagi Ban Israil, bahwa barang siapa yang membunuh seorang manusia, bukan karena orang itu (membunuh) orang lain, atau bukan karena membuat kerusakan di muka bumi, maka seakan-akan dia telah membunuh manusia seluruhnya. Dan barang siapa yang memelihara kehidupan seorang manusia, maka seolah-olah dia telah memelihara kehidupan manusia semuanya. Dan sesungguhnya telah datang kepada mereka rasulrasul Kami dengan (membawa) keterangan-keterangan yang jelas, kemudian banyak di antara mereka sesudah itu sungguh-sungguh melampaui batas dalam berbuat kerusakan di muka bumi".

${ }^{17}$ Syeikh Syaukat Husain, Human Right in Islam, (Terj. Abdul Rochim C.N). Jakarta: Gema Insani Press, 1996, hlm. 60.

18 Terjemahannya : "Dan pada harta-harta mereka ada hak-hak orang miskin yang tidak mendapat bahagian".
} 
d. The right to freedom of opinion and expression.

Islam conferred the right of freedom to think and the right to express opinions to all mankind. This freedom of expression is not only given to citizens against tyranny, but also for individuals to freely express their opinions and at the same time expressing them in relation to various problems. Of course freedom of speech here is related to efforts to promote good deeds and virtues, and strive to appeal and anticipate the various acts of evil and injustice. ${ }^{19}$

e. Equal rights and position before the law.

Islam affirms and emphasizes the equality of all mankind before Allah SWT. As His creatures, man has been created from the same origin, the same ancestor, and to whom they must obey and obey. It is in accordance with the QS. 4 (an-Nisa): $1 .^{20}$

f. The right to freedom of association.

Islam has also given the people the right to freedom of politics, association and forming organizations. However, the right this association is conducted with the motivation to spread and realize the good and good for the individual, the society and the nation, not to spread the evil and the chaos. So it can be said that the right to freedom of association does not apply absolutely and indefinitely. However, he is committed with a passion to spread the good deeds of virtue and godliness, as well as to suppress evil and evil. ${ }^{21}$ The right to freedom of association is generally contained in the QS. 3 (Ali 'Imran): 110). ${ }^{22}$

g. Right to justice.

Islam is present to the earth to uphold justice. So every human servant of Allah SWT gets this very important right of justice. Islam requires its people to uphold justice for their own. It is explicitly explained by Allah SWT in QS. 42 (assh-shura): $15^{23}$

h. Right to get a place to live.

Islam considers that to live as human right in a very urgent human life. So a person can rest in his house of residence that will bring happiness and prosperity for himself, his wife and his family. Ibn Hazm argues: if one does not have a dwelling house and a clear residence, it becomes an obligation for the rich (agniya) to awaken their dhu'afa (weak economic) dwelling place. Even according to Ibn Hazam as also put forward by Ibrahim

${ }^{19}$ Abul A'la Maududi, Human Right in Islam, Aligharh: 1978, hlm.30-31

${ }^{20}$ Terjemahannya : "Hai sekalian manusia, bertakwalah kepada Tuhan-mu yang telah menciptakan kamu dari diri yang satu, dan dari padanya Allah menciptakan isterinya, dan dari pada keduanya Allah memperkembang biakkan laki-laki dan perempuan yang banyak. Dan bertakwalah kepada Allah yang dengan (mempergunakan) nama-Nya kamu meminta satu sama lain, dan (peliharalah) hubungan sillaturrahim. Sesungguhnya Allah selalu menjaga dan mengawasi kamu”.

${ }^{21}$ Syeikh Syaukat Husain, Human Right ..... Op cit....., hlm. 84-85.

${ }^{22}$ Yang Artinya: "Kamu adalah umat yang terbaik yang dilahirkan untuk manusia, menyuruh kepada yang ma`ruf, dan mencegah dari yang munkar, dan beriman kepada Allah. Sekiranya Ahli Kitab beriman, tentulah itu lebih baik bagi mereka; di antara mereka ada yang beriman, dan kebanyakan mereka adalah orang-orang yang fasik".

${ }^{23}$ Yang Artinya: "Sesungguhnya Kami telah mengutus rasul-rasul Kami dengan membawa bukti-bukti yang nyata dan telah Kami turunkan bersama mereka al-Kitab dan neraca (keadilan) supaya manusia dapat melaksanakan keadilan. Dan kami ciptakan besi yang padanya terdapat kekuatan yang hebat dan berbagai manfaat bai manusia, (supaya mereka mempergunakan besi itu) dan supaya Allah mengetahui siapa yang menolong (agama)Nya dan rasul-rasulnya padahal Allah tidak dilihatnya. Sesungguhnya Allah Maha Kuat lagi Maha Perkasa". 
al-Lubban, both argue: the obligation for the state to establish a place of settlement for its impoverished citizens, with no distinction between tribes, nations, race and religion. ${ }^{24}$

\subsection{Political Rights}

Politics is essentially power and decision-making. Its scope starts from the family institution to the highest formal political institution. Therefore, political understanding in principle includes the main issues in everyday life that in fact always involving women. Women's involvement in politics is not meant to impose, degrade, or seize power from men, but is intended to be a male equal partner. ${ }^{25}$

In relation to the political rights, it cannot be separated from the concept of Human Rights which in principle protect the political rights that have been affirmed in the International Covenant on Civil and Political Rights (ICCPR) in essence aims to strengthen the basic human rights in the civil field and politics contained in the Universal Declaration of Human Rights so that they become legally binding provisions and their elaboration covers other related subjects. The Covenant consists of the preamble and articles covering 6 Chapter and 53 Articles on which Indonesia has ratified it into Law no. 12 on 2005. At least according to the researchers, in the ICCPR related to the protection of political rights is divided into 3 (three) parts, namely:

1. Freedom of expression, opinion and access to information;

2. The right to participate in cultural life; and

3. Right to participate in public life and politics

Therefore, with the principle of the ICCPR stating the existence of the right to participate in public life and politics, therefore the role of women in the political world cannot be reduced.

When talking about political rights, must speak to the political man. Political man is meant here is the human as the perpetrator and also the object of politics. Basically all the discourse of political actors has been the study and review of the political fiqh kiab, but in this case there is still the discourse of forgotten political actors, the political discourse of women. As one of the perpetrators and creators of political discourse, women have no meaningful, even marginalized place. Recognized or not, the domain provided by political fiqh, for example about government institutions, such as Imamah, representatives, ministries and so on. It seems more familiar with the activities of men than with women's activities. ${ }^{26}$

Therefore the position of women in political fiqh is an agenda of its own and very important to see. The issue is not merely questioning whether or not women should be imams (leaders), but how the fiqh conception in view of women's political role in general. Broadly speaking, in discussing the existence of the rights of women in politics there are three opinions developed as described below:

a. Conservative Opinion

${ }^{24}$ Abd Wahab `Abd al-`Aziz asy-Syisyani, Huqûq al-Insân wa Hurriyyâtihî al-Asâsiyyah fì an-Nizhâm al-Islâm wa an-Nuzhum li al-Mu`ashirah, Riyad: Jami`ah al-Imam Muhammad bin Sa`ud alIslamiyyah, 1980, hlm.42-43

${ }^{25}$ Siti Musdah Mulia. Muslimah Reformis: Perempuan Pembaru Keagamaan, Bandung, Mizan, 2005, hlm. 275

${ }^{26}$ Syafiq Hasyim, Hal-Hal Yang Tak Terpikiurkan Tentang Isu-Isu Keperempuanan Dalam Islam. Bandung, Mizan, 2001, hlm. 189 
This conservative view argues that in political practice, Islam does not recognize the political equality between men and women. The scholars who support such an opinion, for example, Imam al-Ghozali which states that a woman cannot be positioned as a priest (head of state).

b. Liberal-Progressive Opinion

The liberal-progressive view is that Islam from the outset has introduced the concept of women's involvement in political roles. The group explicitly says that women have the right to vote in politics. They are also allowed to assume the heavy political tasks held by men.

c. Apologist Opinion

The apologist's view is that there is a certain political part of the territory that women can enter and there are certain areas that women cannot touch at all. According to this group, the political area of women is to be a mother.

\section{Discussion}

\subsection{The relationship between Islam, Women and Human Rights}

Talking about the relationship between Islam, Women and Human Rights cannot be separated from the Qur'anic concept of human rights that have been arranged therein. Read the most authoritative source of Islam: al-Qur'an will find many texts that explain respect and respect for human beings. Some of them are:

"And indeed We have glorified the children of Adam. We raise them up on land and sea, We given them rizki from the good and we over them with perfect advantages over most of our creation ". (Q.S. al-Isra, 70).

In another letter the Qur'an also mentions human equality:

"O people We created you from men and women and We made you tribes and nations so that you may know one another. Indeed the most honorable among you with Allah is the most devoted to Him. "(Q.S. al Hujurat, 13).

Two verses above and many other texts explain the glory and equality of human dignity regardless of their origin, color, sex, language and so on. This is the logical consequence of the doctrine of the Lord's Kingdom. All human beings with their various backgrounds at the end come from a single source of God's creation. The superiority that man has over the other man is only in the aspect of his closeness to God.

The other most explicit statement concerning equal rights and duties between men and women is expressed in the Qur'an surah al-Ahzab, 35: "Truly Moslem men and women, believing men and women, men and women who remain in his obedience, the true men and women, men and women who are patient, male and female the devout woman, the sadaqah and the woman who is charitable, the fasting men and women, the men and women who care for their honor, the men and women who many call (name) Allah, Allah has dedicated the forgiveness and the reward which big". Similarly in al Nahl, 97, Ali Imran, 195, al Mukmin 40 and others.

The doctrine of egalitarianism (al-musawah) of Islam above is also stated by Prophet Muhammad SAW. In one of his sayings he said: 
"Humans are like comb teeth, there is no superiority of Arabs over non-Arabs, white people over black, except on the basis of piety to God." His other word is: "Surely, Allah does not judge you on your body and face but on work and your heart". And "Women are the siblings of men".

The statements of the Qur'an and the hadith of the Prophet above it became the basis of the Holy Prophet to declare what was known as "Shahifah Medina", "Mitsaq al Madinah" or Medina Charter, in 622 AD It contained agreements on the rules prevailing in Medina society. Historians claim that this Medina Charter is an authentic manuscript of undoubted authenticity. Some declare it as the world's first human rights declaration.

The Islamic human messages revealed in so many Islamic texts above were formulated in a very impressive manner by Imam Abu Hamid Al Ghazali (1111 AD) and further developed by Abu Ishaq al Syathibi (w $790 \mathrm{H}$ ). Al Ghazali, the greatest classical Sunni Muslim thinker, says that the purpose of religion is social welfare (kemaslahatan). Al Ghazali goes on to explain: "I think the benefit is to realize the religious goals that contain five forms of protection. That is protection against; religion (hifzh al din), soul (hifzh al nafs), mind-mind (hifzh al 'aql), descendants (hifzh al nasl) and possessions (hifzh al maal). Any way that can guarantee the protection of these five principles is the benefit and disregard it is mafsadah, refuse the damage is the benefit." ${ }^{27}$ What is formulated Imam al Ghazali as a religious goal (maqashid al-Shari'ah) is nothing but a mere summary of the principles of religion, the principle of humanity in Islam.

According to KH. Husein Muhammad mentioned that the doctrine of equality (almusawah or egalitarianism) of Islam above was also stated by the Prophet Muhammad. In a hadith: "Humans are like comb teeth, there is no superiority of Arabs over non-Arabs, white people over black, except on the basis of piety to God." (Hadith), then "Really, God does not judge you on your body and face but in your actions and heart". (Hadith).

According to KH. Husein Muhammad, these Qur'anic and hadith statements have been used as a basis for declaring what is known as Shahifah Madinah or Mitsaq al Madinah namely "Medina Charter", in 622 AD The contents include agreements on the rules prevailing in Medina society. Historians claim that this Medina Charter is an authentic manuscript of undoubted authenticity. They declare it as the world's first human rights declaration. ${ }^{28}$

This means that there is no conflict between human rights and HAP declarations with pure Islam. Basic human rights and women's basic rights are not Western-exposed concepts, nor Western ones. In Islam the rights of women and human beings are fully recognized and respected.

Similarly, according to Faqihuddin Abdul Kodir, that Sahaba Umar bin Khattab r.a. states in various occasions: "By Allah, we in the days of ignorance never count women. Then Allah revealed some verses about them, and gave them right. We realized then that they also have an autonomous right where we can no longer intervene ". ${ }^{29}$

According to Faqihuddin some other hadith texts, it has explicitly stated women's rights in domestic life, where previously the right was not owned by women (Arabic period of Jahiliyah). The text of the hadith, among others, is narrated by Hakim ibn Mu'awiyyah ibn Haydah al-Qusyairy, that his grandfather asked the Messenger of Allah: "What are the rights

27 Al-Ghazali, Al Mustashfa min Ilm al Ushul, Tahqiq Dr. Muhammad Sulaiman al-Asyqar, jilid I, Beirut, Al-Resalah, 1997 M/1418 H. hlm.286

${ }_{28}$ KH. Husein Muhammad, HAM dan Gender Dalam Perspektif Islam. http://www.balitbangham.go.id/detail. Dikutip pada 27 Juni 2008

${ }^{29}$ Hadis Bukhari, kitab 77, bab 31, no. 5843 
of the wife?" The apostle replied: "You must feed him as you eat, give him clothes as you wear, do not hit his face, do not harass and do not disobey him by leaving home". ${ }^{30}$

Nevertheless, there are sometimes many conflicting religious texts, between curbing and liberating women. For example, some scholars forbade women to come and enter the mosque. Whereas in the mosque, the center of education, information, politics, and economy, in addition to the place of worship of course.

Such restrictions are usually based on certain Hadith texts concerning threats to seductive women with the fragrances they wore. According to Faqihuddin, ${ }^{31}$ in this case A'ishah ra., Ummul Mukminin has criticized the fatwa, saying that the right to go to the mosque is the same, between men and women. No women should be banned. If the problem is 'disturbing and seductive', then there must be an order for gender, men and women, not just one-sided, women only. Male and female relationships must be disciplined and directed not to fall into low body and moral interest. But for religious and humanitarian work, based on good thoughts and charitable deeds, there must be a balanced space between them.

In the view of the kiai Husein, if there are discrepancies in religious texts that tend to be discriminatory or contradictory, perhaps a wise way of responding is, first, by negating (dismissing) forms of discrimination between people, including in terms of male and female relation. This is because discrimination is inconsistent with the principle of Tawhid (the Word of God). Secondly, by avoiding contradictions in the sacred texts. The Qur'an has stated in its verse: "... not come to him (the Qur'an) evil, from the front or from the back, which is sent down from the most wise, Most Praiseworthy God." (Q.S. Fusshilat, 42)

Perhaps the best way to do this is to reread the sacred texts; The Qur'an, and the hadith of the Prophet as well as texts of the classic book written by scholars. Of course this reading is through the means that allow all to be able to overcome these seemingly contradictory circumstances. Here Kiai Husein invites people to look at all the texts of the Qur'an and the hadith of the Prophet. as the books of instruction for man to achieve a goal. The goal is none other than realizing the mercy (affection and love), and peace for all human beings. Because the Qur'an states: "We did not send you (Muhammad) except to be a mercy to the universe." (Surat al-Ambiya / 21: 107)

\subsection{Islamic views in providing protection to women's political rights}

Until now, women's political participation has undergone massive degradation and reduction process. Women's activity space is restricted to domestic territory and positioned subordinate. This restriction is not only read in textbooks, but also appears in social reality. In fact, the general reason used is that women are seen as a trigger of forbidden sexual relations and their presence in public places is seen as a source of "libel" temptation and stimulates social conflict. This tendentious perception refers to the authoritative sources of Islam (alQur'an and hadith) which are read literally and conservatively. For a long period of interpretative discriminatory views this is widely accepted even by some Muslims today. University of Al-Azhar, has issued a fatwa haram on the basis of Islamic Shari'ah for women to hold public positions (al-region al-'ammah al-mulzimah). Said al Afghani says "al siyasah 'ala al mar'ah haram shiyanah li al mujtama' min al-takhabbuth wa al-u al munqalab" (politics for women is haram to protect society from chaos). Al-Mawdudi from Pakistan and Mustafa al-Siba'i from Syria and a number of other scholars approved this view. Al-Siba'i said that "the

${ }^{30}$ Lihat Ibn al-Atsir, Jami' al-Ushul, juz VII, hal. 357. Lihat juga dalam Faqihuddin Abdul Kodir. Dalam Penegasan Nabi atas Hak-hak Perempuan. Dirasah Hadis, Swara Rahima Edisi 25 tahun 2008.

${ }^{31}$ Faqihuddin Abdul Kodir. Dalam Penegasan Nabi.....Ibid.. 
political role of women in the Islamic view is shunned even I say forbidden. Not this one because he has no expertise but because his social losses are greater, violated Islamic ethics and harmed the interests of the family. "32

The Qur'an speaks of women in various letters and verses concerning the various sides of life. There is also a description of the privilege of female figures in the history of humanity in general, for example in the letter an-Nisa'verse 32 which shows women's rights. Which means, "For men there is a share of what they earn, and for women (too) there is a part of what they earn"

According to the above paragraph the political right of the jurist is the right which is owned and used by a person in his capacity as a member in a political organization such as the right to vote (and elected,) to run for office and to hold public office in the state. In addition, political rights can be interpreted as rights in which individuals contribute through such rights in the management of the state.

Some argue that Islam does not establish equality between women and men, especially in obtaining political rights. The issue of women's right to nomination has two other dimensions: firstly, women become members of parliament, second: to participate in the election of members in parliament.

In order to know the provisions in these two issues, the first contains authority in general affairs, it must be explained that there are two powers, namely First, general authority is the power in the affairs of society, such as the authority of law making, the decision of litigation , implementation of law, and control of law enforcement. Second, special authority is the power to regulate certain issues, such as testament to small children, authority over property, and arrangement of waqf.

The Shari'a provides an opportunity for women in the authority of number two above. In that case, he has the power that men have, as having the power to regulate his special interests. ${ }^{33}$ This opinion is based on At-Taubah's letter: 71: which means: "And those who believe, men and women, some of them are a helper to others. They enjoin goodness, prevent evil, establish prayers, pay zakat, and they are obedient to Allah and His rulers. They will be given mercy by God. Verily Allah is mighty and wise altogether. "(Surat at Taubah [9]: 71). ${ }^{34}$

This verse shows that women are like men. Each of them may participate in politics and organize community affairs, and have the right to govern the public interest.

These political rights include:

a. The right to express and give opinions in policies, elections and referenda in various ways.

b. The right to nominate a member of a representative institution and a local member.

c. The right to nominate for president and other matters of political alliances and communications. ${ }^{35}$

Women are humans who are burdened with obligations just like men. He is obliged to worship Him, establish religion, fulfill duty, keep the unlawful, and preach in goodness and amar ma'ruf nahyi munkar. Divine revelation includes men and women, unless there is a

${ }^{32}$ Muhammad Azhar, Filsafat Politik: Perbandingan Islam dan Barat, Jakarta: RajaGrafindo Persada, 1996, hlm.61

${ }^{33}$ Ikhwan Fauzi, perempuan dan kekuasaan, menulusuri hak politik dan kekuasaan gender dalam Islam, Jakarta, Amzah, 2013, hlm. 36-38

${ }^{34}$ Depag RI, Al-Qur'an dan Terjemahan, Jakarta, Departemen Agama Republik Indonesia. hlm. 291

${ }^{35}$ Mohammad Mais Qosim Ja'far, Perempuan Dan Kekuasaan. Terj. Ikhwan Fauzi, Jakarta, Azan. 2001 , hlm.36 
proposition explaining the specification of revelation only to men. When Allah says: yaa ayyuhan naas (oh all human) or yaa ayyuhal ladziina aamanuu (hai those who believe), then women are also included in it. Ummu Salamah when hearing the Prophet's call: "fateful ayyuhan" (oh man) he immediately answered the call, even though he was preoccupied with his busy life. Companions were astonished at his rashness. "I am also human," said Umm Salamah at that time. ${ }^{36}$

With regard to the position of women and gaining political rights, Islam recognizes the importance of women's role in public life and its impact in political life. Therefore women have been given political rights that reflect their dignified, honorable and noble status in Islam. Some of these rights are as follows:

a. Freedom of Expression.

Exchanging ideas is a very important principle in Islam. The methodology devised by Islam to create a successful nation invites each of its members to counsel each other and deliberate with each other. Allah Almighty says, which means "And to those who receive (obey) the call of his Lord and establish prayer, their affairs (in deciding) by deliberation between them and they spend some of the rizki we give them. (Surah Assh-Shura 42:38) Islam respects the right to freedom of thought and expression of opinion to all mankind. This freedom of expression is not only granted to citizens against tyranny. Also for citizens of a country to be free which to have different opinions and express various problems. $^{37}$

b. Rights Against Elections

Decisions on political matters are deeply reckoned and rewarded in order to have a profound effect on the formation of their own societies. ${ }^{38}$ In the Qur'an Allah says: "O ye who believe, obey Allah and obey Allah's Apostle and Ulil among you, if you differ on the opinion of something, then return it to Allah and the Qur'an and the apostle or His sunnah. And as if you really believe in God and the day after. That is what is more important to you and better consequences. (Surat an-Nisa '4:59).

Thus as a member of the ummah as a whole, women are also entitled to determine their own destiny and the destiny of their nation. Because all individuals have the right to choose the head of state and occupy positions in the ranks of government. ${ }^{39}$ Shura (discussion) according to Al-Quran should be one of the principles of management of areas of common life, including political life. This is in the sense that every citizen in social life is required to always hold deliberations.

c. Right to Get the Protection of Honor

The third important right that Islam provides to women is the protection of honor. Muslims are forbidden to attack each other's honor in any way. This was conveyed by the Prophet on his pilgrimage. The Muslims are bound to guard the honor of others, can be punished by a court of law after proven wrong. The State shall also protect the honor of its citizens without any discrimination. Allah says in the Qur'an: which means "O ye who believe! Let not a people mock some other people because they may be mocked better than they are.... (Surat al-Hujarat 49:11).

d. Oversight Rights

\footnotetext{
${ }^{36}$ Yusuf Qaradhawi, Fiqh.....Ibid.....hlm.161

${ }^{37}$ Fatimah Umar Nasif, Hak Dan Kewajiban Perempuan Dalam Islam. Terj. Burhan Wirasubrata, hlm. 170

${ }^{38}$ Syekh Syaukat Hussein, Human Right In ....Op cit...., hlm. 18

${ }^{39}$ Fatimah Umar Nasif, hak dan kewajiban....Op cit.....hlm. 172
} 
People and individuals have the right to oversee the head of state and all offices of the government. According to their work and behavior concerning about state affairs. This oversight right is intended to straighten the head of state if he deviates from a straight path. It is because Islam has granted the right for all mankind to condemn the injustice of the government.

The Muslim's assumption is that educated women are no better than those who do not have the education to give birth to intelligent children. This means also to equip themselves is a foolish attitude of their own, because we will find the facts of gender equality commonly referred to as "political rights". It includes women's rights in elections, candidates for political office and the right to participate in public affairs. Quran and Islamic history find female figures which follow serious discussions and argue, even against the Prophet himself. ${ }^{40}$ Proven, during the caliph Umar Ibn Khattab came to power, women could freely argue with him in the mosque. Umar revised his statement and turned to support her opinion. Thus was born the pameo since then: "The woman is right, and Umar is wrong." 41

However, again many people give a mistaken interpretation of the hadith. One of the Prophet's hadith explains that women cannot be selected to occupy the highest position at the state level. Clearly, the hadith narrates: "The people will not succeed if they - the women - are allowed to be their leaders." Compared to the height of women's dignity, such a provision will have no effect. Women also remain in their original position as noble humans when compared with the biological and psychological nature of men and women. For the intended Hadith is alqiyadah al-'ammah 'total leadership', general leadership covering a larger society than usual, as does the head of state. As for the other areas, laa maani'a lahu. The scholars agree that the areas of fatwa, ijtihad, education, riwayah, science of hadith, etc. may be occupied by women. In history, it has been done by women for decades. ${ }^{42}$

The Qur'an mentions two types (men and women) responsible for the enforcement and improvement of society with amar ma'ruf nahyi munkar. When the hypocrites play a role in destroying the social order of life, on the part of men there are also hypocrites who can damage society. So for the women which are obliged to improve the state of society as well as men. It is similar with serving the ministry or prime minister. In the time of the Prophet, the first voice echoes the belief of Muhammad's prophet hood. And support him is a woman, Khadija ra., who later became his wife. The first man who shaheed fii sabilillah any woman, namely Samiyyah Ummu Amar r.a.

The arguments we see in the Qur'an and Sunnah are generally applicable to men and women, except the distinction with the background of her feminine nature: in a household, one male and one female. Women have their own laws, menstruation, childbirth, istihadhah, pregnancy, childbirth, breastfeeding, nurturing and so forth. Men have a level of 'qawamah', leadership, responsibility towards the family and the right to provide for the family. There is also a law of inheritance each of which has its own part, two women equal one part of a male. The reason is very clear, because it is calculated based on the difference of hard work and responsibility between men and women.

Thus, there is no obstacle to a woman serving as prime minister, although the jumhur ulama agree to haram woman holds power in al-region al-kubra or al-imamah al-uzhma

\footnotetext{
${ }^{40}$ Lihat QS. Al-Mujadilah (58): 14 dan QS. al-Mumtahanah (60):10-12.

${ }^{41}$ Muhammad 'Atiyyah al-Abrasyi, 'Azamatul Islam, Juz II; Kairo: Maktab al-Usrah, 2002, hlm.270

${ }^{42}$ Yusuf Qaradhawi, Fiqh al-Daulah, t.t: Dar al-Shurq, 1997, hlm.160.
} 
(supreme leader). Whereas women can serve as supreme leaders in government affairs. ${ }^{43}$ But within the limits of leadership in one particular area, which is not comprehensive in society, women deserve it, as in the prosecutor's office, education and even minister. ${ }^{44}$

Finally, the affirmative action policy in women's representation in Parliament has also been able to create equal political rights for women.

\section{Closing}

\subsection{Conclusion}

a. The relationship between Islam, Human Rights and Women is an interrelated relationship. In the Qur'an as the main source of Islamic law we will find many texts that explain respect and respect for human beings, regardless of background of origin, color, language, ethnicity, race, and so on. According to Imam Al-Ghazali that the purpose of religion is social welfare (benefit). The most explicit statement of equality of rights and duties between men and women is expressed in verse 35 of al-Ahzab, which means: "Truly Muslim men and women, believing men and women, men and the women who remain in their obedience, the righteous men and women, men and women who are patient, men and women who are devoted ', the men and women of charity, fasting men and women, men and women who keep their honor, men and women who many call (name) Allah, Allah has provided forgiveness and a great reward ". Similarly in al Nahl, 97, Ali Imran, 195, al Mukmin 40, and others. 32.

b. The Qur'an speaks volumes of women in various letters and verses concerning the various sides of life, and those that describe the privileges of female characters in the history of humanity in general, for example in Surat an-Nisa 'verse 32 which shows the rights of women, which means, "For men there is a share of what they earn, and for women there is a part of what they earn"... some political rights include; 1 ). The right to express and give opinions in policies, elections and referenda in various ways. 2). the right to nominate a member of a representative institution and a local member. 3). Right in the nomination to become president and other matters containing political alliances and communicating opinions. Women have been given political rights that reflect their dignified, honorable and noble status in Islam, among them; 1). The right to freedom of expression. 2). The right to elect. 3). The right to privilege protection. 4). Monitoring rights. With that, Islam provides protection to women's political rights.

\subsection{Suggestions}

a. Need to develop studies about the relationship between Islam, Human Rights and Women, to see the interconnection between them, so as to produce more harmonious relationship between them.

b. Need to conduct more comprehensive comparative studies on women's political rights contained in the Qur'an and also As Sunnah.

\footnotetext{
${ }^{43}$ Muhammad Azhar, Filsafat Politik.....Op cit....hlm.70

${ }^{44}$ Yusuf Qaradhawi, Fiqh.....Op cit.....hlm.248
} 


\section{References}

[1]. adh-Dahahham, Muhammad Muhammad, 1971, Huquq al-Insan fi al-Islam wa Ri ayatihi li alQayyim wa al-Ma ani al-Insaniyyah, Cairo: Syirkah al-Misriyyah.

[2]. al-Abrasyi, Muhammad 'Atiyyah, 2002, 'Azamatul Islam, Juz II; Kairo: Maktab al-Usrah.

[3]. Al-Ghazali, Muhammad, 1964, Al-Islam wa Al-Thaqat Al-Mu'attalat, Kairo, Dar Al-Kutub AlHaditsah.

[4]. -----, 1997 M/1418 H, Al Mustashfa min Ilm al Ushul, Tahqiq Dr. Muhammad Sulaiman al-Asyqar, jilid I, Beirut, Al-Resalah.

[5]. Anderson, Ronald H., 1994, Pemilihan dan Pengembangan Media untuk Pembelajaran (terj. Yusufhadi Miarso, dkk), Jakarta, Raja Grafindo Persada.

[6]. asy-Syisyani, Abd Wahab `Abd al-`Aziz, 1980, Huqûq al-Insân wa Hurriyyâtihî al-Asâsiyyah fí anNizhâm al-Islâm wa an-Nuzhum li al-Mu ashirah, Riyad: Jami`ah al-Imam Muhammad bin Sa`ud al-Islamiyyah.

[7]. az-Zuhaili, Wahbah, 1984, al-Fiqh al-Islam Wa Adillauhu, Juz I, Siria: Dar al-Fikr.

[8]. Azhar, Muhammad, 1996, Filsafat Politik: Perbandingan Islam dan Barat, Jakarta: RajaGrafindo Persada.

[9]. Depag RI, Al-Qur'an dan Terjemahan, Jakarta, Departemen Agama Republik Indonesia.

[10].Effendi, Masyhur, 1994, Dimensi dan Dinamika Hak Asasi Manusia dalam Hukum Nasional dan Internasional, Jakarta, Ghalia Indonesia.

[11].Fauzi, Ikhwan, perempuan dan kekuasaan, menulusuri hak politik dan kekuasaan gender dalam Islam, Jakarta, Amzah.

[12]. Gaus, Geral F. dan Chandran Kukathas, 2013, Handbook Teori Politik, (Terj. Derta Sri Widowatie), Bandung, Nusa Media bekerjasama dengan LPIP.

[13].Hadis Bukhari, kitab 77, bab 31, no. 5843

[14].Hasyim, Syafiq, 2001, Hal-Hal Yang Tak Terpikiurkan Tentang Isu-Isu Keperempuanan Dalam Islam. Bandung, Mizan.

[15].Husain, Syeikh Syaukat, 1996, Human Right in Islam, (Terj. Abdul Rochim C.N). Jakarta: Gema Insani Press.

[16].Ibn al-Atsir, Jami’ al-Ushul, juz VII, hal. 357.

[17].Ja'far, Mohammad Mais Qosim, 2001, Perempuan Dan Kekuasaan. Terj. Ikhwan Fauzi, Jakarta, Azan.

[18].Kodir, Faqihuddin Abdul, Dalam Penegasan Nabi atas Hak-hak Perempuan. Dirasah Hadis, Swara Rahima Edisi 25 tahun 2008.

[19].Marzuki, Peter Mahmud, 2008, Penelitian Hukum, Cet 2. Jakarta: Kencana.

[20].Maududi, Abul A'la, 1978, Human Right in Islam, Aligharh.

[21].Muhammad, KH. Husein, HAM dan Gender Dalam Perspektif Islam. http://www.balitbangham.go.id/detail. Dikutip pada 27 Juni 2008

[22].Muhammad, Abdulkadir, 2004, Hukum dan Penelitian Hukum, Cet. 1. Bandung: PT. Citra Aditya Bakti.

[23].Mulia, Siti Musdah, 2005, Muslimah Reformis: Perempuan Pembaru Keagamaan, Bandung, Mizan.

[24].Nasif, Fatimah Umar, 2001, Hak Dan Kewajiban Perempuan Dalam Islam. Terj. Burhan Wirasubrata, Jakarta, Cendekia.

[25]. Qardhawi, Yusuf, 1997, Fiqh Daulah, Jakarta: Rabbani Press.

[26].-----, 1997, Fiqh al-Daulah, t.t: Dar al-Shurq.

[27].Syihab, Quraish, 2007, Membumikan Al-Qur'an: Fungsi dan Peran Wahyu dalam Kehidupan Masyarakat cet.1, Bandung, Mizan Media Utama.

[28].Syadzali, Munawir. 1996. Islam dan Tata Negara, Jakarta: UI Press.

[29].Tim ICCE UIN Jakarta, 2003. Demokrasi, Hak Asasi Manusia dan Masyarakat Madani, Jakarta : Prenada Media. 